\title{
Detection and characterisation of Complement protein activity in bovine milk by bactericidal sequestration assay
}

\author{
Susan Maye ${ }^{1,2}$, Catherine Stanton ${ }^{1}$, Gerald F Fitzgerald ${ }^{2}$ and Philip M Kelly ${ }^{1 *}$ \\ 'Teagasc Food Research Centre, Moorepark, Fermoy, County Cork, Ireland \\ ${ }^{2}$ School of Microbiology, University College Cork, Cork, Ireland
}

Received 18 November 2014; accepted for publication 31 March 2015; first published online 29 June 2015

\begin{abstract}
While the Complement protein system in human milk is well characterised, there is little information on its presence and activity in bovine milk. Complement forms part of the innate immune system, hence the importance of its contribution during milk ingestion to the overall defences of the neonate. A bactericidal sequestration assay, featuring a Complement sensitive strain, Escherichia coli 0111 , originally used to characterise Complement activity in human milk was successfully applied to freshly drawn bovine milk samples, thus, providing an opportunity to compare Complement activities in both human and bovine milks. Although not identical in response, the levels of Complement activity in bovine milk were found to be closely comparable with that of human milk. Differential counts of Esch. coli 0111 after $2 \mathrm{~h}$ incubation were 6.20 and 6.06 log $\mathrm{CFU} / \mathrm{ml}$, for raw bovine and human milks, respectively - the lower value representing a stronger Complement response. Exposing bovine milk to a range of thermal treatments e.g. 42, 45, 65, 72, 85 or $95^{\circ} \mathrm{C}$ for $10 \mathrm{~min}$, progressively inhibited Complement activity by increasing temperature, thus confirming the heat labile nature of this immune protein system. Low level Complement activity was found, however, in 65 and $72{ }^{\circ} \mathrm{C}$ heat treated samples and in retailed pasteurised milk which highlights the outer limit to which high temperature, short time (HTST) industrial thermal processes should be applied if retention of activity is a priority. Concentration of Complement in the fat phase was evident following cream separation, and this was also reflected in the further loss of activity recorded in low fat variants of retailed pasteurised milk. Laboratory-based churning of the cream during simulated buttermaking generated an aqueous (buttermilk) phase with higher levels of Complement activity than the fat phase, thus pointing to a likely association with the milk fat globule membrane (MFGM) layer.
\end{abstract}

Keywords: Complement, bactericidal activity, milk fat globule membrane, bovine, milk.

Abbreviations: MFGM, Milk fat globule membrane, HTST, high temperature, short time, CFU, colony forming units, SCC, somatic cell count.

As well as being a source of essential nutrients for optimum growth and development, milk provides the neonate with protective elements to support survival of the new-born (Hanssen, 1924; Van Hooijdonk et al. 2000). While the bacteriostatic qualities of milk were recognised as far back as 1924 (Hanssen, 1924) research over the years has focussed on the characterisation of its antimicrobial components such as lactoferrin, lactoperoxidase, lysozyme, peptides derived in vivo during digestion and sialyl-containing oligosaccharides. However, less consideration appears to have been given to the role of another line of defence i.e. the extent

*For correspondence; e-mail: phil.kelly@teagasc.ie to which the innate immune system of the lactating mammal is manifested in its milk secretions. Innate immunity with its physical barriers and cellular components provides non-specific protection as a first line of defence (Ricklin \& Lambris, 2007) which is distinguishable from that of the adaptive immune system that typically responds to specific pathogenic challenge (Galyean et al. 1999). Within innate immunity, Complement consists of serum and membrane proteins which circulate as inactive precursors in the blood system. The triggering of these precursors initiates a cascade of protein cleavages which culminates in the amplification of a cell-killing membrane attack complex (Oviedo-Boyso et al. 2007). Though initiated by different mechanisms, all three established Complement pathways i.e. classical, alternative and mannan-binding 
lectin (MBL) converge at the point when complement component C3 becomes active (Abbas et al. 1994). The classical pathway commences with immune complexation by $\lg \mathrm{G}$ or IgM to pathogens or foreign antigens, the alternative pathway is triggered by either carbohydrates, lipids or proteins found on the surface of foreign microbes or cells in the body, and the MBL pathway is activated when either MBL or Ficolin binds to the surface of pathogens due to carbohydrate moieties (Sarma \& Ward, 2011).

Efforts to date at addressing the presence and role of Complement in human milk (Ogundele, 1998) also lend support to the view that such innate immune components migrate from the circulatory system in the mammary into the secreted milk. However, little is known about its activity in bovine milk and its presence is not even recognised in the recent revision (6th) of the nomenclature of the proteins in cows' milk (Farrell et al. 2004). Lack of suitable assays may have been a contributing factor to this paucity of information. Gradually, the bactericidal sequestration assaybased analytical approach was adapted initially to help identify bactericidal and haemolytic activity of bovine colostrum (Reiter \& Brock, 1975), bovine mastitic milk (Rainard \& Caffin, 1984) and human milk (Ogundele, 1998). The uniqueness of the bactericidal sequestration assay in this case is that growth of a specific pathogenic bacterial strain i.e. Escherichia coli 0111 is sensitive to the presence of Complement, thus exploiting the extent of growth inactivation as an indirect measure of Complement activity present.

Thus, an objective of this study was to adapt and apply the bactericidal sequestration assay used by Ogundele (1998) to establish the level of Complement activity in fresh bovine milk and its comparability with that of human breast milk. A further objective was to evaluate the extent to how such activity may be affected by typical milk processes such as heating and cream separation. This interest was taking place against a backdrop of where advances in the "humanisation' of bovine milk for use as infant feed formula requires a deeper understanding of the biological comparability between both bovine and human breast milk Complement, so that appropriate strategies may be designed for its protection in freshly secreted bovine milk during the course of dairy manufacturing processes.

\section{Material and methods}

\section{Sample preparation}

Milk samples. Fresh whole bovine milk was collected from the Moorepark Dairy Production Centre (MDPC) farm on the day of testing. The somatic cell counts (SCC) of the freshly collected milk was determined using Bentley Somacount $300^{\circledR}$ (Bentley Instruments Inc., Chaska MN, USA), SCC of $<200000 \mathrm{cells} / \mathrm{ml}$ was required for use of the milk.

Fresh commercial products including cream, full fat milk and low fat milk were purchased from local supermarkets on the day of testing.
Human milk was collected from the Western Health and Social Care Trust (Glenshane Road, Londonderry BT47 6SB, United Kingdom) and was stored in aliquots at $-80^{\circ} \mathrm{C}$ until required.

Control preparation. Freshly collected raw milk was heat treated at $56^{\circ} \mathrm{C}$ for $30 \mathrm{~min}$ to ensure complete inactivation of the Complement protein (Korhonen et al. 2000a). All samples were screened using the International Dairy Federation (IDF) methods (IDF, 2004, 2013) and also the milks were streaked on Nutrient and Luria Bertani agar.

Effect of heat treatment. Individual milk samples were exposed to a range of temperatures: $42,45,65,72,85$ and $95^{\circ} \mathrm{C}$ with $10 \mathrm{~min}$ holding time before bactericidal sequestration assay in order to determine the effect of heating on Complement activity (Korhonen et al. 2000b). Milk samples were heat-treated using Hettich Elbanton special products oil bath (Hettich Benelux B.V., De Aaldor 9-4191 PC Geldermalsen, Netherlands) with rocking arm to ensure uniform heat treatment throughout the samples. A control sample generated by heating at $56^{\circ} \mathrm{C}$ for 30 min was used as reference for complete Complement inactivation.

Milk samples separation and washing. An Armfield disc bowl centrifuge (Armfield, Ringwood, UK) was used to generate cream samples (approximately $40 \%$ fat) and skimmed milk (approximately $1 \%$ fat) from the fresh raw milk. The cream was then stored at $4{ }^{\circ} \mathrm{C}$ overnight and the following morning a Kenwood Chef food mixer (Model KM220, Harvant, Hants, UK) was used to disrupt the cream emulsion resulting in the production of butter. From this buttermilk was released and was filtered through glass wool to remove butter grains. Human milk was thawed overnight at $4{ }^{\circ} \mathrm{C}$. This was then separated by centrifugation at $2000 \mathrm{~g}$ for 15 min at $4{ }^{\circ} \mathrm{C}$ (Patton \& Huston, 1986) in order to separate the fat fraction.

Washed buttermilk was prepared using the Armfield disc bowl centrifuge however, an additional step was incorporated whereby the cream was suspended in sterile distilled water and held at $37^{\circ} \mathrm{C}$ for $1 \mathrm{~h}$ to wash the buttermilk. The separation procedure was repeated (Armfield disc bowl centrifuge) and cream collected. This step was repeated twice more.

\section{Bacterial strain}

Escherichia coli 0111 (Esch. coli NCTC 8007, serotype 0111 K58(B4)) a pathogenic Complement sensitive strain was purchased from Health Protection Agency Culture Collections (Health Protection Agency Culture Collections Porton Down Salisbury Wiltshire, SP4 0JG UK). This strain was routinely grown in Luria-Bertani (LB) medium at $37^{\circ} \mathrm{C}$ with shaking. Standard LB broth and agar was prepared as described Sambrook et al. (2001). 


\section{Bactericidal sequestration assay}

Esch. coli 0111 was prepared for overnight growth at $37^{\circ} \mathrm{C}$ on LB agar. An isolated colony from replicate plates was inoculated into 3 tubes of LB broth (Merck KGaA, Darmstadt, Germany) and grown overnight at $37^{\circ} \mathrm{C}$. The overnight cultures were centrifuged at $392 \mathrm{rcf}$, a pellet was formed, the supernatant was removed and the pellet was re-suspended in phosphate buffer saline solution $(1 \times$ PBS solution) this step was repeated twice. On the final step the pellet was suspended in LB broth and adjusted to $3 \times 10^{8}$ colony forming units (CFU) per $\mathrm{ml}$ using the McFarland Method (Goldman et al. 1986). Using 96-well plates $3 \times 20$ $\mu \mathrm{l}$ of each of the three replicate cultures was added to each round bottomed well (SARSTEDT Ltd, Wexford, Ireland) and $80 \mu \mathrm{l}$ of the sample to be tested was then added. The plate was incubated at $37^{\circ} \mathrm{C}$ for $2 \mathrm{~h}$ shaking at $200 \mathrm{rpm}$ (Model Mini 4450 SHKA4450-1CE, Fischer Scientific, Ballycoolin, Dublin). A $20 \mu$ l sample was taken from each well after the incubation time and total viable counts enumerated on LB agar using the pour plate method.

\section{Serum susceptibility assay}

The blood serum susceptibility assay developed by Hogan et al. (1989) was adapted by substituting blood with milk. Freshly collected bovine milk $(125 \mu \mathrm{l})$ and heat treated milk (control; $125 \mu \mathrm{l}$ ) were added to individual wells of a 96-well plate, subsequently $100 \mu$ l Tris- $\mathrm{NaCl}_{2}$ buffer was added $(1 \times$ Sigma Chemical Company, St. Louis, MO). The next step was the addition of $25 \mu \mathrm{l}$ of the Esch. coli 0111 inoculum which had been grown to a level of $10^{6} \mathrm{CFU} / \mathrm{ml}$. The 96well plate was incubated at $37^{\circ} \mathrm{C}$ and viability of the bacteria evaluated at 0 and $4 \mathrm{~h}$. Viable bacteria were plated on nutrient agar (Merck KGaA, Darmstadt, Germany) for $15 \mathrm{~h}$ at $37{ }^{\circ} \mathrm{C}$ and results were expressed in terms of differential growth between the serum susceptibility assay and nutrient agar. This was accomplished by subtracting the initial amount of colonies $(0 \mathrm{~h})$ from the final number of viable colonies $(4 \mathrm{~h})$.

\section{Results}

Comparison of Complement-associated bactericidal activity in bovine and human milks

The sequestration assay relies on the specific sensitivity of Esch. coli 0111 to the presence of Complement, thus, an active Complement system in milk would be expected to retard growth of the strain. Furthermore, since Complement is known to be inactivated at temperatures $>56{ }^{\circ} \mathrm{C}$ for $30 \mathrm{~min}$ (Korhonen et al. 2000a) it is, thus, possible to compare growth of Esch. coli 0111 in heated v. raw milk the differential in growth rates between the heated (control) and raw milks being attributable to Complement activity. This was evident when comparing the growth of Esch. coli in heat-treated $\left(56{ }^{\circ} \mathrm{C}, 30 \mathrm{~min}\right)$ milk, freshly collected raw bovine milk and human milk (Fig. 1) where differential

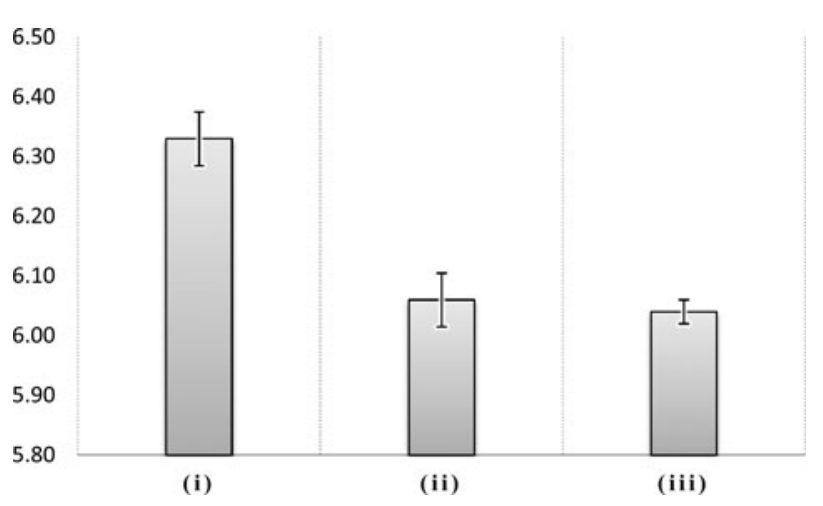

Fig. 1. Differential reduction in Esch. coli $0111(\log 10 \mathrm{CFU} / \mathrm{ml})$ during bactericidal sequestration assay of (i) heated bovine milk (control), (ii) raw bovine milk and (iii) human milk, after inoculation and after $2 \mathrm{~h}$ incubation.

counts after $2 \mathrm{~h}$ incubation at $37^{\circ} \mathrm{C}$ were 6.32, 6.20 and 6.06 viable colonies of Esch. coli 0111 (log CFU/ml), respectively - the lower value indicating a more effective Complement response. This corresponded to cell reduction factors of 0.12 and $0 \cdot 26(P<0 \cdot 01)$ following incubation with raw bovine milk and human milk, respectively. Following analysis for normality it was determined that a KruskalWallis test should be applied to the differential data, the results of which confirmed that there was a statistical difference $(P<0 \cdot 01)$ between all three samples, which was supported further by a Mann-Whitney test to show that both raw bovine milk and human milk were significantly different $(P<0 \cdot 01)$ from the control (heat-treated milk).

\section{Growth characteristics of Esch. coli 0111}

The growth characteristics of Esch. coli 0111 was compared by incubating the strain separately in nutrient broth or bovine milk overnight at $37^{\circ} \mathrm{C}$ in order to have an improved understanding of its vitality during deployment in the bactericidal sequestration assay.

The Esch. coli 0111 strain grew steadily on nutrient agar starting from an initial viable colony count of $7 \cdot 18$ to reach 8.98 log CFU/ml after $24 \mathrm{~h}$ incubation (Fig. 2). Growth of the strain in bovine milk peaked at $8.56 \mathrm{log} \mathrm{CFU} / \mathrm{ml}$ at $13 \mathrm{~h}$ during the same period after which it declined slightly.

Complement activity was also evident when Esch. coli was inhibited in untreated wells during a serum susceptibility assay of forewarmed $\left(56^{\circ} \mathrm{C}, 30 \mathrm{~min}\right)$ and non-heated bovine milk. The plated viable colonies reached peak growth of 8.0 and $8.95 \mathrm{log}$ cells/ml after incubation with the raw bovine and heated bovine milks (control), respectively $(P<0 \cdot 05)$.

\section{Investigation of Complement activity in cream separated bovine milk}

Preliminary laboratory work carried out on the variation between freshly collected bovine milk and in-store 


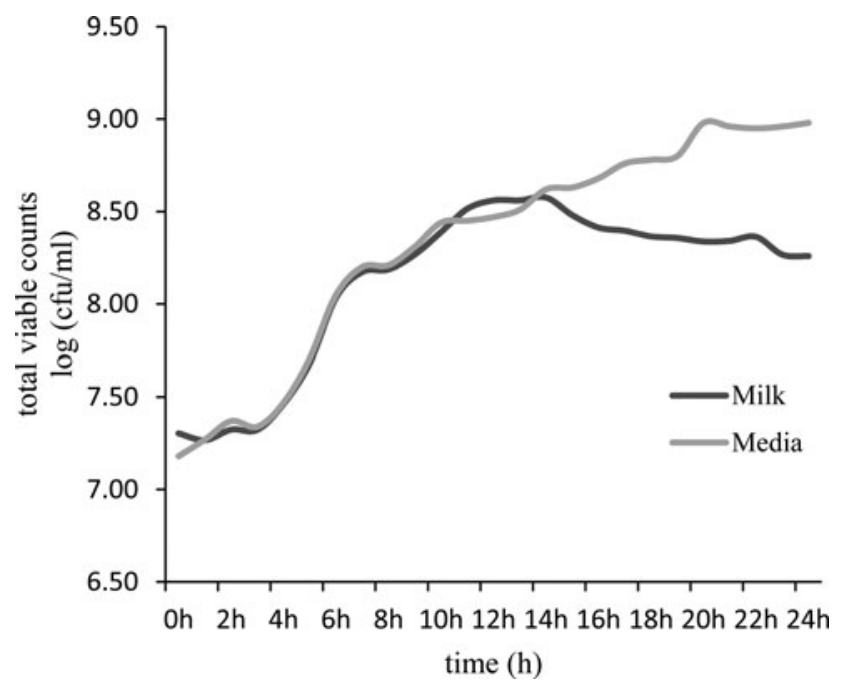

Fig. 2. Total viable counts of Esch. coli $0111(\log 10 \mathrm{CFU} / \mathrm{ml})$ during incubation at $37^{\circ} \mathrm{C}$ for $24 \mathrm{~h}$ in nutrient broth and bovine milk.

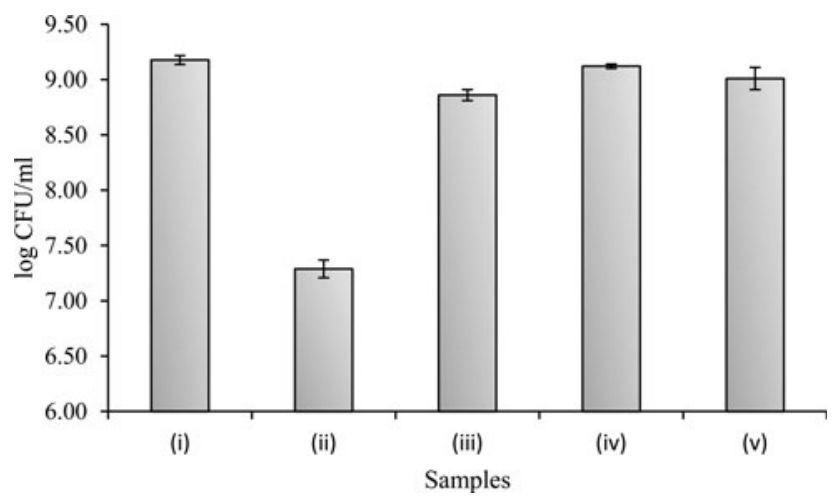

Fig. 3. Total viable counts of Esch. coli $0111(\log 10$ CFU/ml) after $2 \mathrm{~h}$ following incubation in (i) heated bovine milk (control), (ii) raw bovine milk and (iii) retail pasteurised milk, (iv) raw bovine skim milk, (v) retail pasteurised low fat milk during the bactericidal sequestration assay for for $2 \mathrm{~h}$ at $37^{\circ} \mathrm{C}$.

purchased full-fat milk was extended to include low-fat ( $1 \%$ fat) retail milks and skim milk prepared by cream separation in the laboratory from freshly collected raw bovine milk (Fig. 3). Subsequent to assessment for normality, a Kruskal-Wallis test revealed that there was a statistically significant difference $(P<0 \cdot 001)$ in colony forming units across the five groups [control (heat inactivated milk), raw milk, retailed full-fat milk, skim milk, retailed low-fat milk]. The raw untreated bovine milk was more effective in inhibiting growth of Esch. coli 0111 than the pasteurised sample. The lower-fat milk variants (in-store purchased and labprepared) were also less effective in reducing growth of the Complement-sensitive strain. Further statistical analysis, which examined individual groups (Mann-Whitney test), confirmed that full fat raw milk was significantly different from all other samples $(P<0 \cdot 005)$.

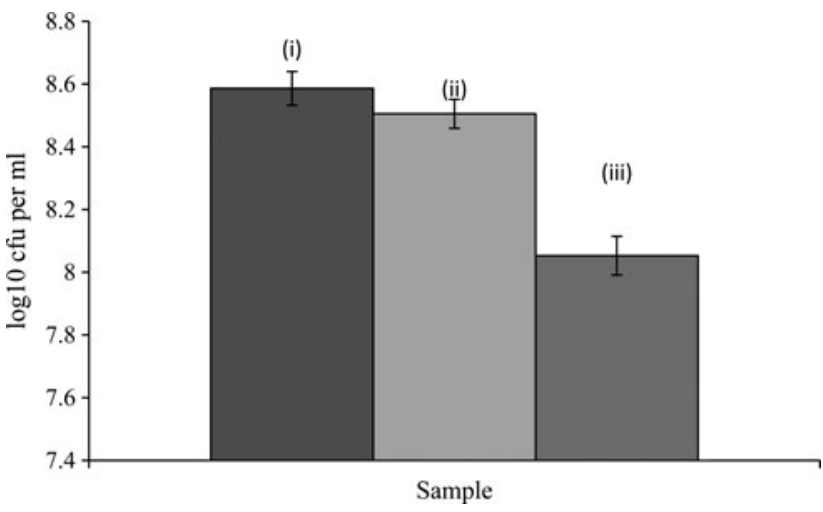

Fig. 4. Total viable counts of Esch. coli 0111 (log10 CFU/ml) after $2 \mathrm{~h}$ incubation in (i) heat treated bovine milk (control), (ii) lab prepared skim human breast milk, (iii) human breast milk in accordance with the bactericidal sequestration assay.

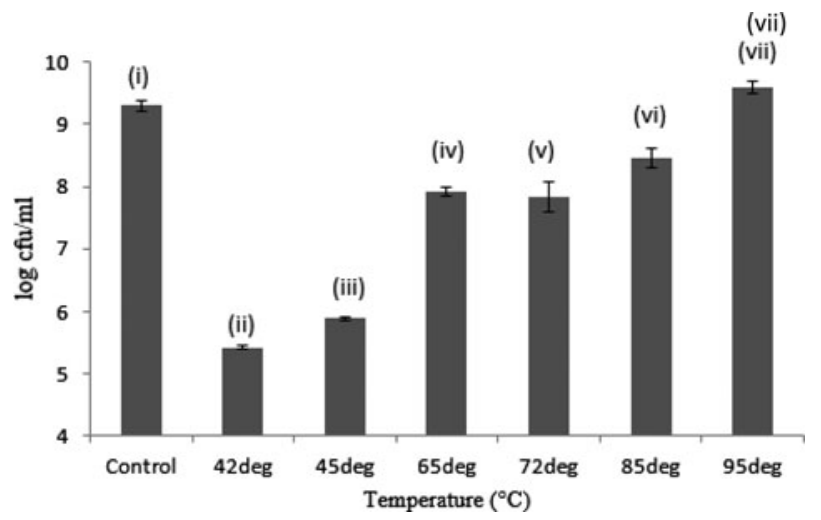

Fig. 5 Total viable counts of Esch. coli 0111 following $2 \mathrm{~h}$ incubation in bovine milk heated at (i) $56^{\circ} \mathrm{C}, 30 \mathrm{~min}$ (control), (ii) $42{ }^{\circ} \mathrm{C}, 10 \mathrm{~min}$, (iii) $45^{\circ} \mathrm{C}, 10 \mathrm{~min}$, (iv) $65^{\circ} \mathrm{C}, 10 \mathrm{~min}$, (v) $72{ }^{\circ} \mathrm{C}$, $10 \mathrm{~min}$, (vi) $85^{\circ} \mathrm{C}, 10 \mathrm{~min}$, (vii) $95^{\circ} \mathrm{C}, 10 \mathrm{~min}$, in accordance with bactericidal sequestration assay for $2 \mathrm{~h}, 37^{\circ} \mathrm{C}$.

\section{Effect of fat reduction in human milk}

Laboratory centrifugation (Patton \& Huston, 1986) was used to defat (remove the upper cream layer) human milk since the available volume was too small for treatment by conventional dairy cream separation technology.

Similar to bovine milk, the full-fat form of human milk was significantly $(P<0.05)$ more effective than the defatted/ skimmed human milk (Fig. 4), thus confirming the association between Complement and fat phase of the milks of both species at a microstructure level.

\section{Effect of heat treatment on Complement activity}

The bactericidal sequestration assay was performed on bovine milks which had been heated to each of the following temperatures: $42,45,65,72,85$ or $95^{\circ} \mathrm{C}$ with holding for $10 \mathrm{~min}$ and compared with that of bovine milk heated to $56^{\circ} \mathrm{C}$ for 30 min as control (Fig. 5). Maximum Complement activity 


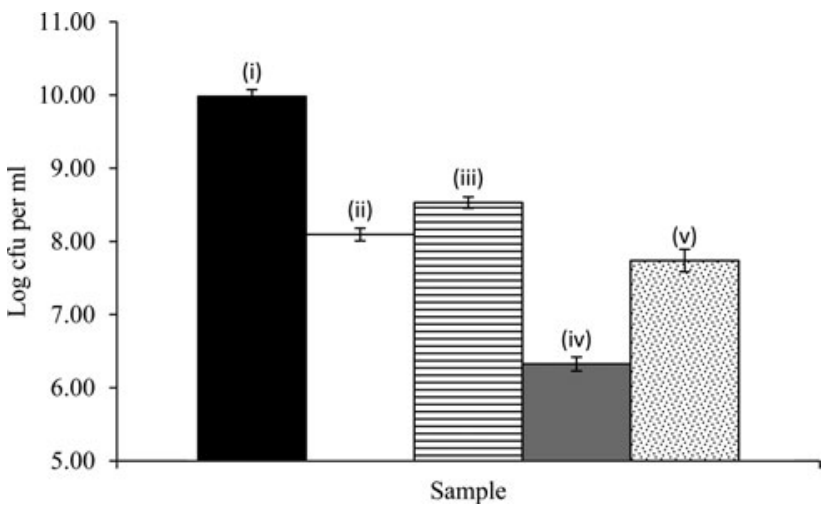

Fig. 6. Total viable counts of Esch. coli $0111(\log 10 \mathrm{CFU} / \mathrm{ml})$ following $2 \mathrm{~h}$ incubation in (i) heated bovine milk, $56{ }^{\circ} \mathrm{C}, 30 \mathrm{~min}$ (control), (ii) cream $(\sim 40 \%$ fat) prepared from freshly collected raw bovine milk (iii) retail pasteurised cream, (iv) lab prepared buttermilk from cream of raw milk (v) lab prepared buttermilk made from the cream (washed twice at $37^{\circ} \mathrm{C}$ for $1 \mathrm{~h}$ ) of raw milk, after $2 \mathrm{~h}$ incubation at $37^{\circ} \mathrm{C}$ according to the a bactericidal sequestration assay.

$(5 \cdot 41 \log \mathrm{CFU} / \mathrm{ml})$ was observed at $42{ }^{\circ} \mathrm{C}$ followed by a slight loss (5.89 $\log \mathrm{CFU} / \mathrm{ml})$ as the temperature increased to $45^{\circ} \mathrm{C}$. Based on assay counts of 7.82-7.92 log CFU/ml, a sizeable loss in Complement activity occurred when these milks were heated to either 65 or $72{ }^{\circ} \mathrm{C}$ for $10 \mathrm{~min}$ (Fig. 5). At the same time, the residual Complement activity associated with the latter two temperatures falling within batch pasteurisation $\left(65^{\circ} \mathrm{C}, 30 \mathrm{~min}\right)$ and continuous high temperature, short time (HTST) holding conditions $\left(72^{\circ} \mathrm{C}, 15 \mathrm{~s}\right)$ concurs with its low level presence in retailed, commercially pasteurised milks referred to earlier. Further increases in temperature (85 or $95{ }^{\circ} \mathrm{C}$ for $10 \mathrm{~min}$ ) continued to inactivate Complement. All samples were significantly different from one another $\chi^{2}$ $(6, n=21)=28.566, P<0.001$ (Fig. 5). Further post-hoc comparisons using the Mann-Whitney test to look at individual samples identified that there was no significant difference between 65 and $72{ }^{\circ} \mathrm{C}(P<0 \cdot 05)$.

\section{Comparison of cream and buttermilk samples}

Buttermilk is known to be rich in milk fat globule membrane (MFGM) components (El-Loly, 2011). The Complement activity of buttermilks was significantly $(P<0.05)$ greater than that of the creams from which they were generated according to the Kruskal Wallis test (Fig. 6). The buttermilk prepared from the cream of raw milk was significantly different $(P<0 \cdot 01)$ from the laboratory-prepared cream, retail cream and the washed buttermilk samples based on the Mann-Whitney test of comparing each group individually A loss of bactericidal sequestration activity in the buttermilks generated from washed cream would suggest that Complement components were removed to some extent into the aqueous phase.

\section{Discussion}

This study confirms that Ogundele's (1998) bactericidal sequestration assay which uses a specific strain of Esch. coli to detect the presence of Complement activity in human milk may now be extended for similar assay detection in bovine milk. The bactericidal sequestration assay confirmed the presence and activity of Complement in bovine milk, this also suggests that both human and bovine milks are broadly analogous in terms of their sequestration response (Figs 1 \& 4).

This is an interesting finding given the complexity of Complement with its $30+$ proteins and protein fragments that there should be considerable homology between human and bovine milks. Thus, the milks of both species would appear to share the same amplifying Complement cascade that builds up to the activation of a cell-killing membrane attack complex (Ogundele, 2001). The results in Fig. 1 - also highlight that the bactericidal sequestration assay was adaptable to allow for the direct comparison of human and bovine milk, thus making it possible to further investigate various bovine milk by-product streams and also milks subjected to different process treatments.

Exposure to a range of thermal treatments 42, 45, 65, 72, 85 and $95{ }^{\circ} \mathrm{C}$ for 10 min progressively inhibited Complement activity (Fig. 5). The initial loss in Complement activity over the course of a $3{ }^{\circ} \mathrm{C}$ rise during heating of bovine milk from 42 to $45^{\circ} \mathrm{C}$ highlights how heat labile these immune proteins are. Fortuitously, some residual Complement activity is still detectable in and around typical milk pasteurisation temperatures whether by batch heating or HTST methods. This concurred also with assay results generated with samples of commercially retailed pasteurised milks. Testing of fresh untreated and retail pasteurised bovine milks in both full and low fat variants provided the first indication that Complement activity appeared to be greater in milks containing a higher fat content (Fig. 3). This was confirmed in the course of a follow-up study involving cream separation of milk by either gravity-induced or centrifugally-employed methods which showed that greater Complement activity was detectable in the milk fat enriched phase of both bovine and human milk Attempts at cream dilution to ascertain if there was a relationship between Complement response and fat content were not conclusive. This may have been due to limitations with the microbiological assay as a prozone-based inhibition effect has previously been described (Rainard \& Caffin, 1984; Ogundele, 2001). In any case, Complement-based sequestration of Esch. coli 0111 was no longer observed in samples where milk fat was depleted or substantially reduced in the case of raw and retail low-fat milks. Simulated buttermaking of the prepared creams enabled Complement activity to be tracked during further partitioning between the fat and aqueous (buttermilk) phases. Potent Complement activity evident in buttermilk samples suggests that it most likely associates with the MFGM components present. MFGM has already been shown to exhibit some antibacterial properties 
(Singh, 2006). MFGM as a tri-layer of both proteins and lipids from the endoplasmic reticulum membrane and mammary epithelium cells that envelopes the lipids in milk (Mather, 1999) is also a carrier of biologically active molecules like phospholipids, sphingolipids, cholesterol and other bio-functional proteins (Lopez, 2011; Lopez et al. 2011).

Overall, it can be seen that the Complement system is present in bovine milk and while heat labile, a certain amount of activity is detectable after milk pasteurisation. Although not identical in response, the levels of Complement activity in bovine milk are closely comparable with that of human milk. Complement's association with the fat phase of milk has implications for the development of low fat variants of fresh dairy products, and indeed where milk fat is replaced by non-dairy fat sources in infant formula. Future studies should aim to further investigate the factors that influence Complement activity in bovine milk and methods to retain its activity during processing.

Susan Maye is in receipt of a Teagasc Walsh Fellowship. Financial support by the Department of Agriculture, Food and the Marine is gratefully acknowledged.

\section{References}

Abbas AK, Lichtman AH \& Pillai S 1994 Cellular and Molecular Immunology, 6 edn. Philadelphia: Elsevier Health Sciences

El-Loly MM 2011 Composition, properties and nutritional aspects of milk fat globule membrane-a review. Polish Journal of Food and Nutrition Sciences 61 7-32

Farrell Jr H, Jimenez-Flores R, Bleck G, Brown E, Butler J, Creamer L, Hicks C, Hollar C, Ng-Kwai-Hang K \& Swaisgood H 2004 Nomenclature of the proteins of cows' milk_sixth revision. Journal of Dairy Science 87(6) 1641-1674

Galyean M, Perino L \& Duff G 1999 Interaction of cattle health/immunity and nutrition. Journal of Animal Science 77 1120-1134

Goldman A, Thorpe L, Goldblum R \& Hanson L 1986 Anti-inflammatory properties of human milk. Acta Paediatrica 75 689-695

Hanssen FS 1924 The bactericidal property of milk. British Journal of Experimental Pathology $\mathbf{5} 271$

Hogan JS, Todhunter DA, Smith KL \& Schoenberger PS 1989 Serum susceptibility of coliforms isolated from bovine intramammary infections 1. Journal of Dairy Science 72(7) 1893-1899

IDF 2004 ISO 21187/IDF 196. Milk - Quantitative Determination of Bacteriological Quality - Guidance for Establishing and Verifying a Conversion Relationship between Routine Method Results and Anchor
Method Results. Geneva, Switzerland: International Organization for Standardization, and Brussels, Belgium: International Dairy Federation

IDF 2013 ISO 16917/IDF 161. Milk - Bacterial Count - Protocol for the Evaluation of Alternative Methods. Geneva, Switzerland: International Organization for Standardization, and Brussels, Belgium: International Dairy Federation

Korhonen H, Marnila P \& Gill H 2000a Milk immunoglobulins and complement factors. British Journal of Nutrition 84 75-80

Korhonen H, Marnila P \& Gill HS 2000b Milk immunoglobulins and complement factors. British Journal of Nutrition 84 S75-S80

Lopez C 2011 Milk fat globules enveloped by their biological membrane: unique colloidal assemblies with a specific composition and structure. Current Opinion in Colloid \& Interface Science 16(5) 391-404

Lopez C, Briard-Bion V, Ménard O, Beaucher E, Rousseau F, Fauquant J, Leconte N \& Robert B 2011 Fat globules selected from whole milk according to their size: different compositions and structure of the biomembrane, revealing sphingomyelin-rich domains. Food Chemistry 125(2) 355-368

Mather IH 1999 A review and proposed nomenclature for major proteins of the milk-fat globule membrane. Journal of Dairy Science 83(2) 203-247

Ogundele MO $1998 \mathrm{New}$ insights into the role of milk fat globule membrane in the sequestration of particulate antigens: interactions with the complement system. In Proceedings of the 5th Internet World Congress for Biomedical Sciences

Ogundele MO 2001 Role and significance of the complement system in mucosal immunity: particular reference to the human breast milk complement. Immunology and Cell Biology 79(1) 1-10

Oviedo-Boyso J, Valdez-Alarcon JJ, Cajero-Juarez M, Ochoa-Zarzosa A, Lopez-Meza JE, Bravo-Patino A \& Baizabal-Aguirre VM 2007 Innate immune response of bovine mammary gland to pathogenic bacteria responsible for mastitis. Journal of Infection 54 399-409

Patton S \& Huston GE 1986 A method for isolation of milk fat globules. Lipids 21 170-174

Rainard PPB \& Caffin JP 1984 Assessment of hemolytic and bactericidal complement activities in normal and mastitic bovine milk. Journal of Dairy Science 67 614-619

Reiter B \& Brock J 1975 Inhibition of Escherichia coli by bovine colostrum and post-colostral milk. I. Complement-mediated bactericidal activity of antibodies to a serum susceptible strain of $E$. coli of the serotype O 111 . Immunology $\mathbf{2 8} 71$

Ricklin D \& Lambris JD 2007 Complement-targeted therapeutics. Nature biotechnology 25 1265-1275

Sambrook J, Russell DW \& Russell DW 2001 Molecular Cloning: A Laboratory Manual (3-volume set). Cold Spring Harbor, NY: Cold Spring Harbor Laboratory Press

Sarma JV \& Ward PA 2011 The complement system. Cell and Tissue Research 343 227-235

Singh H 2006 The milk fat globule membrane-a biophysical system for food applications. Current Opinion in Colloid \& Interface Science 11(2) 154-163

Van Hooijdonk ACM, Kussendrager KD \& Steijns JM 2000 In vivo antimicrobial and antiviral activity of components in bovine milk and colostrum involved in non-specific defence. British Journal of Nutrition $\mathbf{8 4}$ S127-S134 